\title{
Primary Epithelial Myoepithelial Carcinoma of Lung, Reporting of a Rare Entity, Its Molecular Histogenesis and Review of the Literature
}

\author{
Farzana Arif, ${ }^{1}$ Susan Wu, ${ }^{1}$ Shahriyour Andaz, ${ }^{2}$ and Stewart Fox ${ }^{2}$ \\ ${ }^{1}$ Department of Pathology, South Nassau Communities Hospital, One Healthy Way, Oceanside, NY 11572, USA \\ ${ }^{2}$ Department of Thoracic Surgery, South Nassau Communities Hospital, One Healthy Way, Oceanside, NY 11572, USA
}

Correspondence should be addressed to Farzana Arif, farif@verizon.net

Received 25 February 2012; Accepted 20 May 2012

Academic Editors: I. A. Chaudhry, D. Miliaras, and Y. Nagashima

Copyright (C) 2012 Farzana Arif et al. This is an open access article distributed under the Creative Commons Attribution License, which permits unrestricted use, distribution, and reproduction in any medium, provided the original work is properly cited.

\begin{abstract}
Primary epithelial myoepithelial carcinoma of lung is a rare entity and is thought to arise from the submucosal bronchial glands distributed throughout the lower respiratory tract. Because of the rarity of this tumor, we describe one case of epithelial myoepithelial carcinoma arising in the bronchus intermedius and presenting as an endobronchial mass. A 57-year-old male patient presented with an incidental finding of an endobronchial mass located in the lumen of the right lower lobe bronchus and caused near total luminal occlusion of the bronchus. An endobronchial carcinoid tumor was entertained clinically. Subsequently the patient underwent an uneventful videothoracoscopic lobectomy of lower and middle lobes of the right lung. Morphologically and immunohistochemically the tumor was characterized by two cell populations with epithelial and myoepithelial cells forming duct-like structure. The final diagnosis of epithelial myoepithelial carcinoma of lung was rendered.
\end{abstract}

\section{Case Presentation}

57-year-old male patient presented with colicky abdominal pain located at the previous incisional hernia site of the anterior abdominal wall. He had a history of smoking 1 cigarette pack per day for 20 years but quit over 10 years ago. His work up included a CT scan of the abdomen including slices from the lower chest. There was an incidental finding of an endobronchial mass of 2.0 centimeters in diameter and the mass almost entirely occluded the lumen of the right lower lobe bronchus. Patient denied any history of cough, shortness of breath, hemoptysis, fever, or weight loss. A PET/CT scan showed low-grade uptake with an SUV of 1.8 in the mass (Figure 1). Fibreoptic bronchoscopy showed a friable, smooth, and highly vascular looking mass in the right lower bronchus. Clinical diagnosis was endobronchial carcinoid tumor. The patient denied symptoms of a carcinoid syndrome, such as, flushing, diarrhea, wheezing, and cyanosis. Subsequently he underwent an uneventful videothoracoscopic right lower and middle lobectomy.

\section{Materials and Methods}

The tissue was fixed in 10\% buffered formalin for 24 hours and embedded in paraffin. Sections were taken and stained with hematoxylin eosin. The immunohistochemical stains were performed at an outside facility, using the Leica polymer detection system Intense on the BondMax staining platform. The following antibodies and proteins were used: Cytokeratins AE1/AE3 (Invitrogen, Frederick MD; 1:400), CAM5.2 (BD Biosciences, San Jose, CA, USA; $1: 200$ ), CK7 (DAKO, Carpinteria, CA, USA; 1:8,000), CK903 (DAKO, Carpinteria, CA, USA; 1:250), S-100 (DAKO, Carpinteria, CA, USA; $1: 10,000)$, Calponin (DAKO, Carpinteria, CA, USA; $1: 2,000$ ), SMA (BioCare Medical, Concord, CA, USA; $1: 400$ ), GFAP (Invitrogen, Frederick, MD, USA; 1:50), CD117 (DAKO, Carpinteria, CA, USA; 1:250), Synaptophysin (BioGenex, San Ramon, CA, USA; 1:400), Chromogranin (DAKO, Carpinteria, CA, USA; $1: 4,000$ ), Thyroglobulin (DAKO, Carpinteria, CA, USA; $1: 50,000$ ), TTF1 (Thermo Scientific, Freemont, CA, USA; 1,000), CK20 


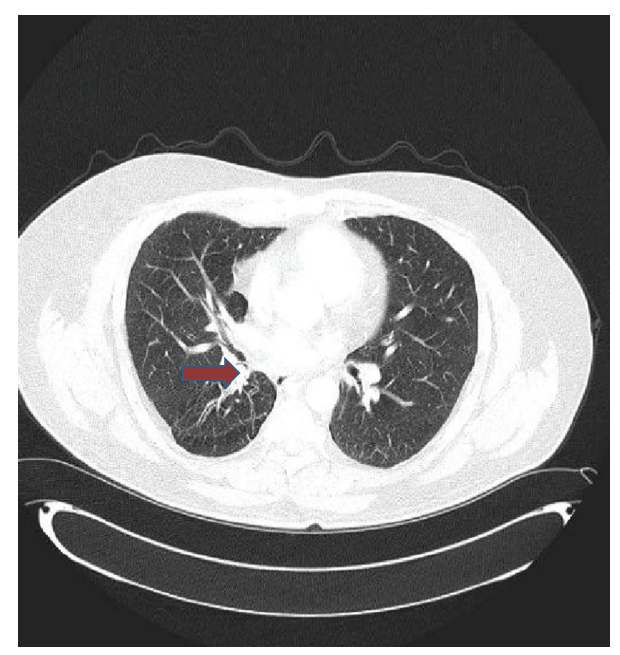

FIGURE 1: CT scan showing endobronchial mass (red arrow).

(DAKO, Carpinteria, CA, USA; $1: 2,000$ ), BerEP4 (DAKO, Carpinteria, CA, USA; $1: 400$ ), B72.3 (Covance, Emeryville, CA, USA; $1: 2,000$ ), PSA (DAKO, Carpinteria, CA, USA; $1: 16,000)$ and Ki-67 (DAKO, Carpinteria, CA, USA; readyto-use (pre-diluted) and p27/Kip1 (DAKO, Carpinteria, CA, USA; $1: 200)$ (Table 2).

\section{Pathology}

Grossly, the tumor was a solitary, well-circumscribed, whitetan, polypoid, and unencapsulated mass located in the bronchus intermedius. It measured $1.2 \times 1.0 \times 0.8 \mathrm{~cm}$ in greatest dimension (Figure 2). Cut surface was solid whitish tan with no evidence of necrosis or hemorrhage. Microscopically, the mass was situated beneath the bronchial epithelium without capsule. The mass was composed of duct like structures, lined by two distinct cell layers. The inner cell layer was cuboidal cells with eosinophilic cytoplasm and centrally located nuclei and outer layer of cells with predominantly clear cytoplasm and uniform nuclei. The ducts like structures contained eosinophilic material in the luminal spaces. Some areas of the tumor showed more spindly cells with clear cytoplasm (Figures 3 and 4). The tumor showed 23 mitosis/10 high-power field (HPF). Immunohistochemical studies confirmed the biphasic nature of the tumor. The inner layer of ducts was reactive for cytokeratins (CAM5.2, AE1/AE3, CK7 and CK903) indicating epithelial cells differentiation, and outer layer of cells was reactive for S100, calponin, SMA, GFAP suggestive of myoepithelial cells. CD117 showed positive reactivity in ducts and spindle cells (Figures 5, 6, 7, 8, and 9). The tumor did not show reactivity for synaptophysin, chromogranin, thyroglobulin, TTF- 1 and CK20, BerEP4, B72.3, and PSA. Ki-67 showed 2-3\% of proliferative activity (Figure 10). Immunostain for p27/kip1 was performed and it showed nuclear reactivity in the epithelial component and minimal cytoplasmic positivity in the myoepithelial component (Table 2).

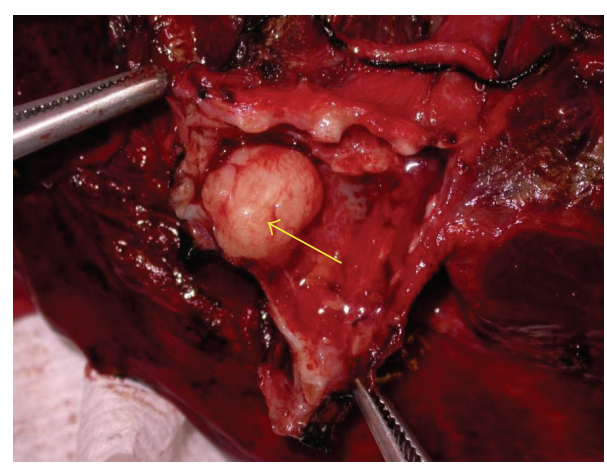

FIgURE 2: Gross, well-circumscribed endobronchial tumor.

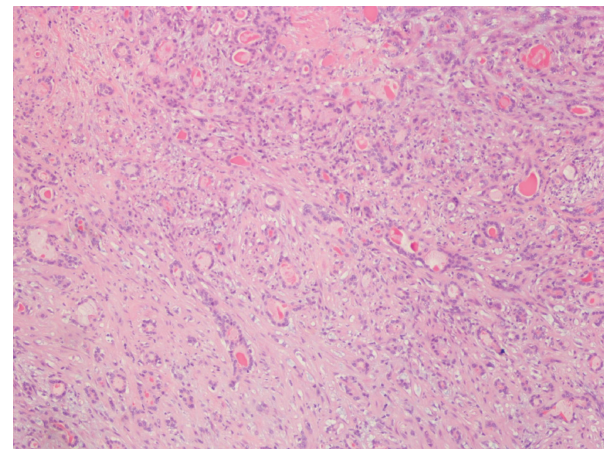

Figure 3: Tumor, duct-like structures and spindle areas (hematoxylin eosin, original magnification $\times 100$ ).

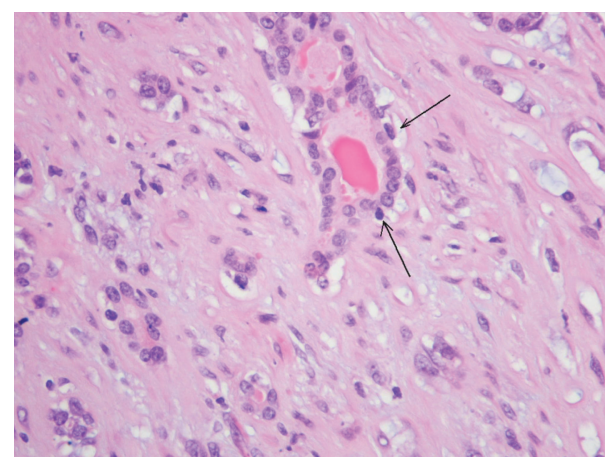

Figure 4: Tumor, inner glandular layer, and outer myoepithelial layer (hematoxylin eosin, original magnification $\times 400$ ).

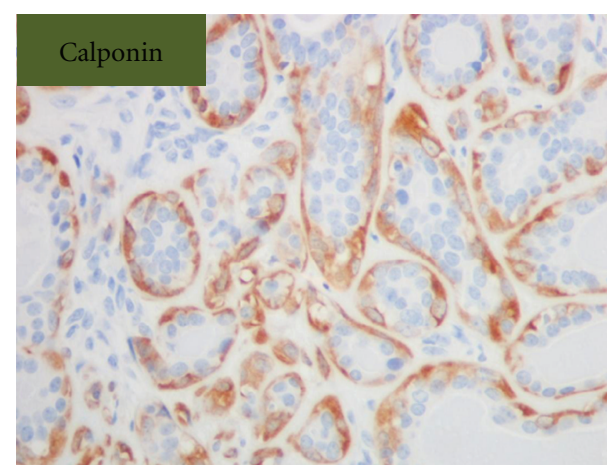

FIGURE 5: Myoepithelial stains, calponin, (original magnification $\times 400$ ). 


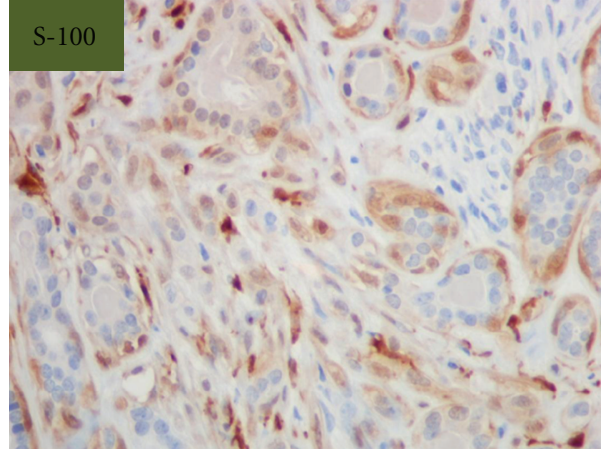

FIGURE 6: Myoepithelial stains, S-100 (original magnification $\times 400)$.

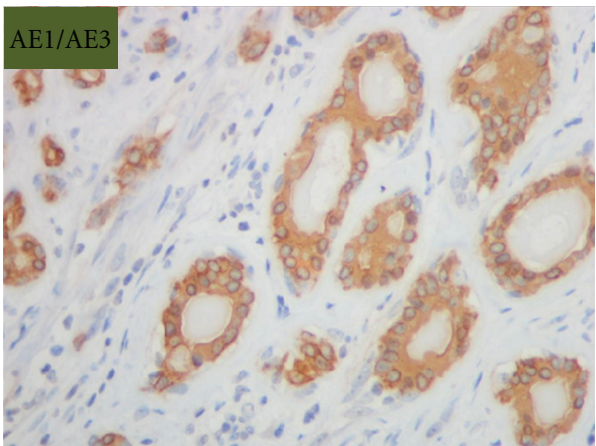

FIGURE 7: Epithelial stains, AE1/AE3 (original magnification $\times 400$ ).

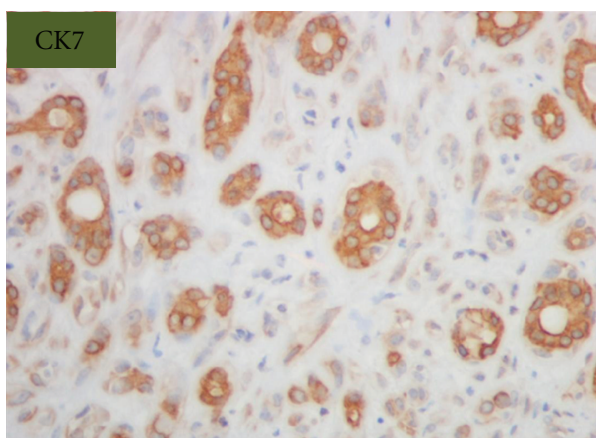

FIGURE 8: Epithelial stains, CK7 (original magnification $\times 400$ ).

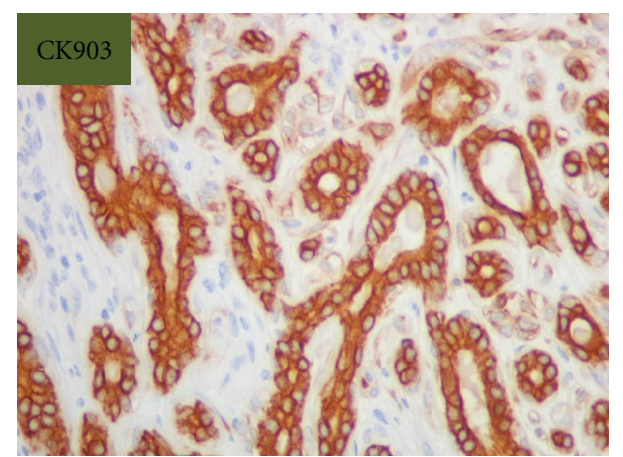

FIGURE 9: Epithelial stains, CK903 (original magnification $\times 400$ ).

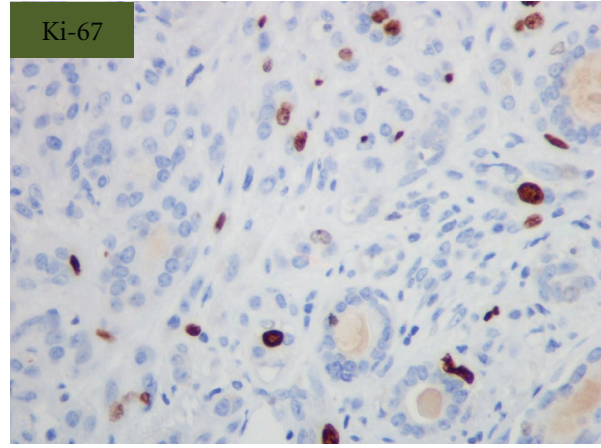

FIGURE 10: Ki-67 shows 2-3\% proliferative activity (original magnification $\times 400)$.

\section{Discussion}

Primary epithelial myoepithelial tumors of lung are rare neoplasms. These tumors are considered to be low-grade malignant neoplasms with histologic features similar to their counterparts of the salivary gland. Neoplasms with similar morphology are reported in the breast, skin, and lacrimal glands [12-14]. It is a relatively less common entity that had only been recognized within the last 2 decades [12]. The WHO defines this entity as "a malignant tumor composed of variable proportions of two-cell types, which typically form duct like structures. The biphasic morphology is represented by an inner layer of duct lining, epithelial type cells, and an outer layer of clear myoepithelial cells" [15]. To date, 24 cases have been reported in the lung, variably classified as "adenomyoepithelioma", "pneumocytic adenomyoepithelioma", "myoepithelioma", "epithelial myoepithelial carcinoma", and epithelial myoepithelial tumor. One suggested term by Pelosi was pulmonary epithelial myoepithelial tumor of unproven malignant potential (PEMTUMP) $[7,12]$.

A review of the literature reveals a total of 25 cases including the current case in the last 18 years. Out of 25 cases, there is slightly female predominance, 15 are females and 10 are males. Age range is $34-76$ years and the average age is 54 years. 13 cases arise on the right side, 11 arise on left side, and one case does not state the site. The size of the tumor ranges from $0.8 \mathrm{~cm}$ to $16 \mathrm{~cm}$; with average of $3.2 \mathrm{~cm}$. Sizes are not available in two cases. Most of the cases are presented as polypoid endobronchial mass. Grossly these tumors are not encapsulated but well-delineated masses, and they present as an exophytic intrabronchial growth pattern, sometimes completely obstructing the bronchial lumina [13]. One recent case is described as being intraparenchymatous mass without apparent bronchial or visceral pleura connection [13]. All cases show characteristic morphology with biphasic pattern of an inner layer of epithelial cells immunoreactive for cytokeratins and an outer layer of myoepithelial cells immunoreactive for S-100 and smooth muscle actin (SMA). Few cases show a solid component with spindle and clear cells including our case, and the solid component in most of the cases shows positive reactivity for myoepithelial markers. A PAS-positive, diastase-sensitive amorphous material is observed in the intercellular spaces and luminal spaces 
TABLE 1

\begin{tabular}{|c|c|c|c|c|c|c|c|c|c|}
\hline Year & Case author & Age & Sex & Diagnosis & Site & $\begin{array}{c}\mathrm{Siz} \\
(\mathrm{cm})\end{array}$ & Lymph node & Met & Outcome \\
\hline 1994 & Nistal et al. [1] & 55 & $\mathrm{~F}$ & EMT & RUL & 2 & \multirow[t]{18}{*}{ N/A } & \multirow[t]{18}{*}{ Neg } & FOD at $2 \mathrm{yr}$ \\
\hline 1993 & Hornouchi [2] & 57 & $\mathrm{~F}$ & EMT & Trachea & 2.2 & & & $\mathrm{~N} / \mathrm{A}$ \\
\hline 1995 & Tsuji et al. [3] & 66 & M & $\begin{array}{l}\text { Adenomyo } \\
\text { epithelioma }\end{array}$ & $\begin{array}{l}\mathrm{R} \text { intermedius } \\
\text { bron }\end{array}$ & 1.6 & & & $\begin{array}{l}\text { AW after } 36 \text { months now } \\
\text { died of unrelated disease }\end{array}$ \\
\hline 1997 & $\begin{array}{l}\text { Wilson and Moran } \\
{[4]}\end{array}$ & 55 & $\mathrm{~F}$ & EMC & LLL & 3.9 & & & AW after $7 \mathrm{~m}$ \\
\hline 1998 & Shanks et al. [5] & 67 & M & EMC & LLL & 1.3 & & & Lost to follow up \\
\hline 1998 & Ryska et al. [6] & 47 & $\mathrm{~F}$ & EMC & RULB & N/A & & & AW after $13 \mathrm{~m}$ \\
\hline 2001 & Pelosi et al. [7] & 47 & $\mathrm{M}$ & $\begin{array}{l}\text { EMT of unprovn } \\
\text { malig potential }\end{array}$ & LULB & 1.5 & & & AW after 6 months \\
\hline \multirow{4}{*}{2001} & \multirow{4}{*}{ Fulford et al. [8] } & $1: 55$ & $\mathrm{~F}$ & EMC & $\mathrm{RMB}$ & 5 & & & FOD at 8 months \\
\hline & & $3: 56$ & M & EMC & & N/A & & & FOD at $5 \mathrm{yrs}$ \\
\hline & & $4: 57$ & $\mathrm{~F}$ & EMC & LMB & 1.5 & & & FOD at 8 yrs \\
\hline & & $5: 54$ & $\mathrm{~F}$ & EMC & RUL & 1.5 & & & FOD at $7 \mathrm{yrs}$ \\
\hline 2003 & Doganay et al. [9] & 73 & M & EMC & LLLB & 5 & & & AW after $34 \mathrm{~m}$ \\
\hline 2004 & Ru et al. [10] & 73 & M & EMC & LULB & 3.8 & & & FOD at 8 months \\
\hline \multirow{7}{*}{2007} & \multirow{5}{*}{ Chang et al. [11] } & $1: 54$ & $\mathrm{~F}$ & Pneumocytic & RLL & 2.6 & & & FOD at 31 months \\
\hline & & $2 ; 62$ & $\mathrm{~F}$ & adenomyoepithelioma & LLL & 2 & & & FOD at 14 months \\
\hline & & $3 ; 58$ & $\mathrm{~F}$ & & RML & 1.2 & & & FOD at 13 months \\
\hline & & $4 ; 57$ & $\mathrm{~F}$ & & LUL & 0.8 & & & FOD at 78 months \\
\hline & & $5 ; 52$ & $\mathrm{~F}$ & & RUL & 1.2 & & & FOD at 5 months \\
\hline & \multirow{5}{*}{ Nguyen et al. [12] } & $1 ; 38$ & $\mathrm{M}$ & EMC & LLL & 5 & \multirow{2}{*}{$\begin{array}{c}\text { One case } \\
\text { shows lymph }\end{array}$} & & FOD at 4 months \\
\hline & & $2 ; 48$ & M & EMC & RUL & 2.5 & & & FOD at 12 months \\
\hline \multirow[t]{3}{*}{2009} & & $3 ; 52$ & $\mathrm{~F}$ & EMC & LLL & 3 & \multirow[t]{3}{*}{ node inv } & & N/A \\
\hline & & $4 ; 54$ & M & EMC & RUL & 3 & & & FOD at 12 months \\
\hline & & $5 ; 56$ & $\mathrm{~F}$ & EMC & $\begin{array}{l}\text { L main } \\
\text { bronchus }\end{array}$ & 4.2 & & & FOD at 2 months \\
\hline 2011 & Munoz et al. [13] & 76 & $\mathrm{~F}$ & EMC & RUL & 2.7 & & & N/A \\
\hline & current case & 57 & M & EMC & $\begin{array}{c}\text { Right } \\
\text { bronchus } \\
\text { intermedius }\end{array}$ & 1.2 & & & FOD at 9 months \\
\hline
\end{tabular}

EMC: epithelial myoepithelial carcinoma, EMT: epithelial myoepithelial tumor, RUL: right upper lobe, LLLB: left lower lobe bronchus, RULB: right upper lobe bronchus, LULB: left upper lobe bronchus, RMB: right main bronchus, RLL: right lower lobe, RML: right middle lobe, RUL: right upper lobe, LLL: left lower lobe, LUL: left upper lobe, LMB: lower main bronchus, FOD: free of disease, AW: alive with, N/A: not available.

of duct-like structures. Necrosis is rare, but it has been described [15]. Ki-67 labeling is reported in few cases and it ranges from $<1 \%$ to $12 \%$. Since there are only few cases reported in the literature with limited followup, the overall approach is to complete excision of these tumors because of infiltrating morphologic pattern. So far there is only one case that showed extensive lymphovascular, perineural invasion, and lymph node involvement and local metastasis [12]. Followup of 22 out of 25 cases ranges from 4 months to 7 years. No followup is available in three cases including one case lost to followup. The rest of cases reported no recurrence or distant metastasis (Table 1). The disease-free survival and lack of nodal involvement in majority of cases correlate well with the lack of recognized histopathologic features of aggressiveness [8].
The biologic behavior of this type of tumor is still unclear. Attempts were made by Pelosi et al. to find out the changes at molecular level and further supported by Munoz et al. [13] Protein p27/kip-1 is a cyclin-dependent kinase inhibitor (CDK) that blocks cell cycle in G0 and G1. It is present in high concentration in quiescent cells and its levels slowly decrease while cells are stimulated to begin the cell cycle. Thus, p27/kip-1 inhibits and controls the progression of the cell cycle and therefore exercises a function of inhibition of tumorigenesis; in fact, it has been demonstrated that levels of p27/kip-1 are decreased in many tumors. Moreover, Besson et al. have recently described a dual function of this protein; as well as acting as an inhibitor of tumorigenesis, it would have oncogenic functions when it presents cytoplasmic location, acting through mediators 
TABLE 2

\begin{tabular}{|c|c|c|c|c|c|c|c|c|c|}
\hline & CAM5.2 & AE1/AE3 & CK7 & CK903 & S-100 & Calponin & SMA & CD117 & GFAP \\
\hline $\begin{array}{l}\text { Source and } \\
\text { dilution }\end{array}$ & $\begin{array}{l}\text { BD Biosciences, } \\
\text { San Jose, CA, } \\
\text { USA; } 1: 200\end{array}$ & $\begin{array}{l}\text { Invitrogen, } \\
\text { Frederick, } \\
\text { MD, USA; } \\
1: 400\end{array}$ & $\begin{array}{l}\text { DAKO, } \\
\text { Carpinte- } \\
\text { ria, CA, } \\
\text { USA; } \\
1: 8000\end{array}$ & $\begin{array}{l}\text { DAKO, } \\
\text { Carpinte- } \\
\text { ria, CA, } \\
\text { USA; } \\
1: 2000\end{array}$ & $\begin{array}{c}\text { DAKO, } \\
\text { Carpinteria, } \\
\text { CA, USA; } \\
1: 10000\end{array}$ & $\begin{array}{c}\text { DAKO, } \\
\text { Carpinteria, } \\
\text { CA, USA; } \\
1: 2000\end{array}$ & $\begin{array}{l}\text { BioCare Medical, } \\
\text { Concord, CA, } \\
\text { USA; } 1400\end{array}$ & $\begin{array}{l}\text { DAKO, } \\
\text { Carpinte- } \\
\text { ria, CA, } \\
\text { USA; } \\
1: 250\end{array}$ & $\begin{array}{l}\text { Invitrogen, } \\
\text { Frederick, } \\
\text { MD, USA; } \\
1: 50\end{array}$ \\
\hline Epithelial cell & Positive & Positive & Positive & Positive & Negative & Negative & Negative & Negative & Negative \\
\hline $\begin{array}{l}\text { Myoepithelial } \\
\text { cells }\end{array}$ & Negative & Negative & Negative & Negative & Positive & Positive & Positive & Positive & Positive \\
\hline
\end{tabular}

which are little known [16]. The work also suggests that p27/kip-1 oncogenic activity leads to aberrant stem and progenitor cell expansion in the lung and retina. This study provides the first direct in vivo evidence that in addition to its role as a tumor suppressor, p27/kip-1 also functions as an oncogene. So, in epithelial-myoepithelial tumors of lung, in accordance with Pelosi et al. [7], an aberrant subcellular location of p27/kip-1 into the myoepithelial cell would provoke the loss of its growth-inhibition function through the lack of restriction of proliferation of myoepithelial component. Munoz et al. support this concept along with proved oncogenic function of this protein [13]. In our case, nuclear epithelial positivity is more pronounced. There is minimal cytoplasmic positivity seen in the myoepithelial component which verifies this concept, but evaluation of more cases is needed to support this concept. In conclusion, epithelial-myoepithelial tumor is a neoplasia of uncertain malignant potential, which can arise exceptionally in the lung.

Epithelial myoepithelial carcinoma is not difficult to diagnose in resection specimen because of characteristic morphology and immunohistochemical studies. Only in very scant biopsy material or sampling of areas without the characteristic bilayered tubules may cause difficulty and confusion with other neoplasms [12].

The differential diagnosis can be extensive and in many occasions it is going to depend on the relative predominance of myoepithelial component or on the biphasic pattern. If the tumor has predominantly biphasic pattern, the differential diagnosis includes pulmonary pleomorphic adenoma. If there is predominance of clear cells (myoepithelial cells) then myoepithelioma, myoepithelial carcinoma, and clear cell "sugar" tumor are in differential diagnosis. Clear cell "sugar" tumor can be differentiated on immunohistochemical stains since these tumors show positivity for melanocytic markers like HMB-45 and negativity for cytokeratins. If a tumor shows infiltrating pattern with some solid areas, mucoepidermoid carcinoma, acinic cell carcinoma, adenoid cystic carcinoma, and metastatic renal cell carcinoma are other differentials to consider. Surgical resection appears to be the treatment of choice by any of the current surgical modalities and depending on the clinical setting.

\section{References}

[1] M. Nistal, M. Garcia-Viera, C. Martinez-Garcia, and R. Paniagua, "Epithelial-myoepithelial tumor of the bronchus,"
The American Journal of Surgical Pathology, vol. 18, no. 4, pp. 421-425, 1994.

[2] H. Horinouchi, T. Ishihara, M. Kawamura et al., "Epithelial myoepithelial tumor of the tracheal gland," Journal of Clinical Pathology, vol. 46, pp. 185-187, 1993.

[3] N. Tsuji, R. Tateishi, S. Ishiguro, T. Terao, and M. Higashiyama, "Adenomyoepithelioma of the lung," The American Journal of Surgical Pathology, vol. 19, no. 8, pp. 956-962, 1995.

[4] R. W. Wilson and C. A. Moran, "Epithelial-myoepithelial carcinoma of the lung: immunohistochemical and ultrastructural observations and review of the literature," Human Pathology, vol. 28, no. 5, pp. 631-635, 1997.

[5] J. H. Shanks, P. S. Hasleton, A. Curry, and A. Rahman, "Bronchial epithelial-myoepithelial carcinoma," Histopathology, vol. 33, no. 1, pp. 90-91, 1998.

[6] A. Ryska, Z. Kerekes, E. Hovorkova et al., "Epithelial carcinoma of the bronchus," Pathology-Research and Practice, vol. 194, pp. 431-435, 1998.

[7] G. Pelosi, F. Fraggetta, F. Maffini, P. Solli, A. Cavallon, and G. Viale, "Pulmonary epithelial-myoepithelial tumor of unproven malignant potential: report of a case and review of the literature," Modern Pathology, vol. 14, no. 5, pp. 521-526, 2001.

[8] L. G. Fulford, Y. Kamata, K. Okudera et al., "Epithelialmyoepithelial carcinomas of the bronchus," The American Journal of Surgical Pathology, vol. 25, no. 12, pp. 1508-1514, 2001.

[9] L. Doganay, S. Bilgi, A. Ozdil, Y. Yoruk, S. Altaner, and K. Kutlu, "Epithelial-myoepithelial carcinoma of the lung: a case report and review of the literature," Archives of Pathology \& Laboratory Medicine, vol. 127, no. 4, pp. e177-e180, 2003.

[10] K. Ru, A. Srivastava, and A. S. Tischler, "Bronchial epithelialmyoepithelial carcinoma," Archives of Pathology and Laboratory Medicine, vol. 128, no. 1, pp. 92-94, 2004.

[11] T. Chang, A. N. Husain, T. Colby et al., "Pneumocytic adenomyoepithelioma: a distinctive lung tumor with epithelial, myoepithelial, and pneumocytic differentiation," The American Journal of Surgical Pathology, vol. 31, no. 4, pp. 562$568,2007$.

[12] C. V. Nguyen, S. Suster, and C. A. Moran, "Pulmonary epithelial-myoepithelial carcinoma: a clinicopathologic and immunohistochemical study of 5 cases," Human Pathology, vol. 40, no. 3, pp. 366-373, 2009.

[13] G. Munoz, F. Felipo, I. Marquina, and C. Del Agua, "Epithelial-myoepithelial tumour of the lung: a case report referring to its molecular histogenesis," Diagnostic Pathology, vol. 6, article 71, 2011.

[14] L. E. Clarke and J. T. Seykora, "Primary cutaneous adenomyoepithelioma," Journal of Cutaneous Pathology, vol. 34, no. 8, pp. 654-657, 2007. 
[15] I. Fonseca and J. Soares, "Epithelial myoepithelial carcinoma," in World Health Organization Classification of Tumors, Pathology and Genetics of Head and Neck Tumors, L. Barnes, J. W. Eveson, P. Reichart, and D. Sidransky, Eds., pp. 225-226, IARC Press, Lyon, France, 2005.

[16] A. Besson, H. C. Hwang, S. Cicero et al., "Discovery of an oncogenic activity in p27Kip1 that causes stem cell expansion and a multiple tumor phenotype," Genes \& Development, vol. 21, no. 14, pp. 1731-1746, 2007. 


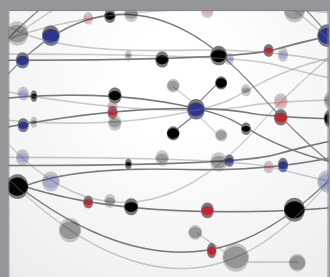

The Scientific World Journal
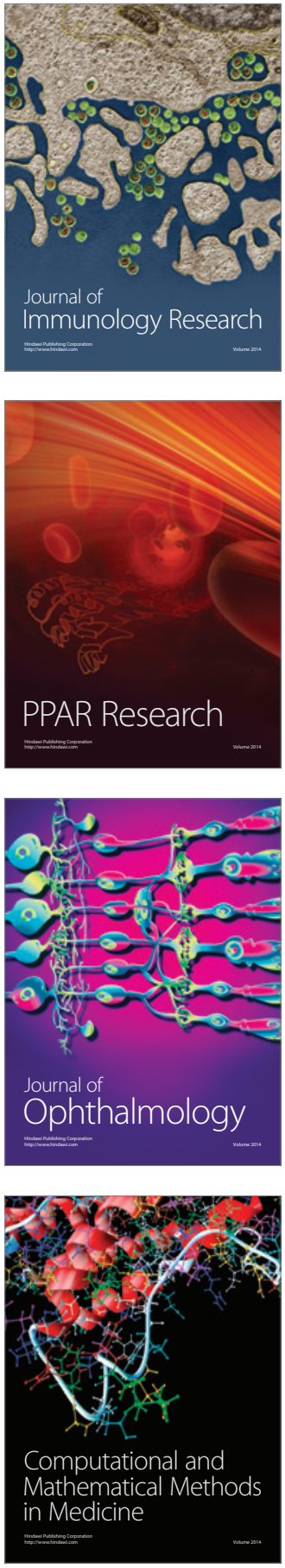

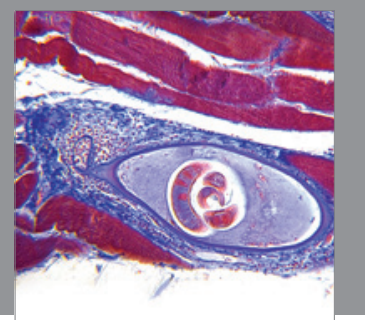

Gastroenterology

Research and Practice
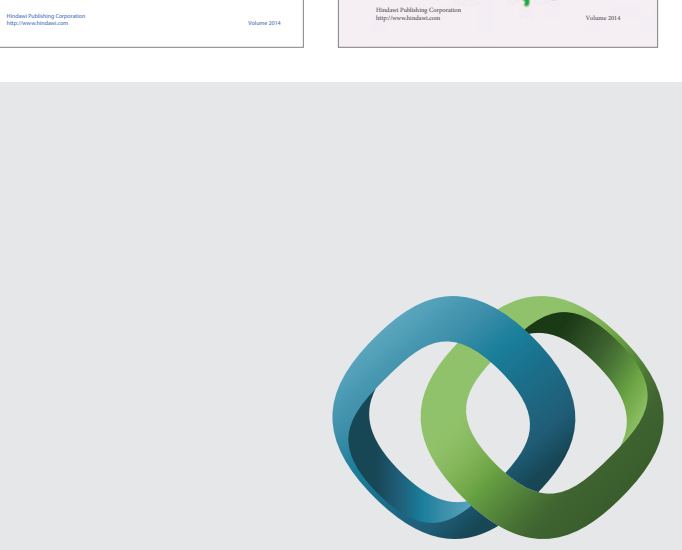

\section{Hindawi}

Submit your manuscripts at

http://www.hindawi.com
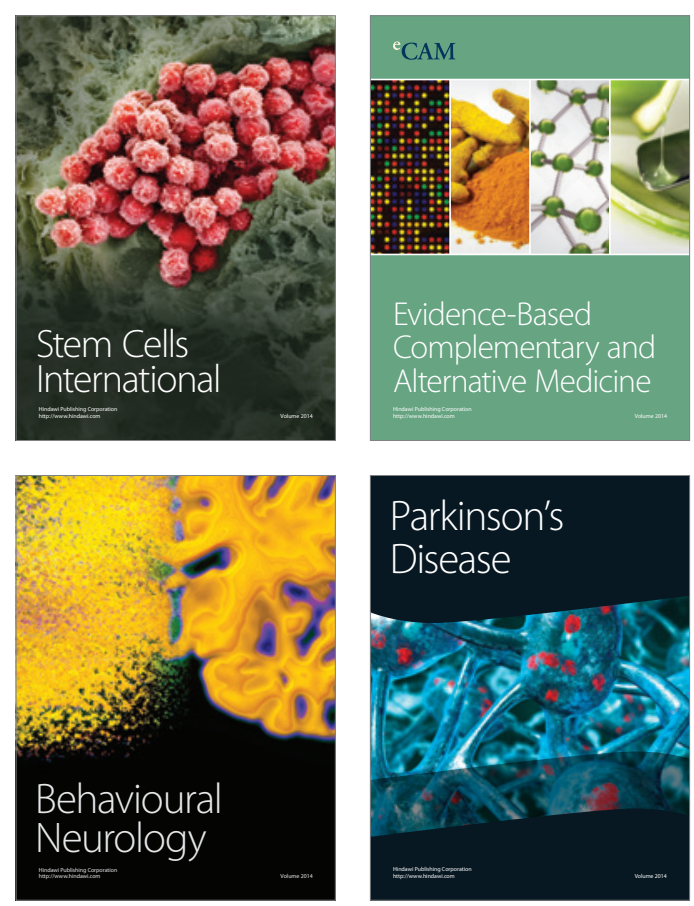

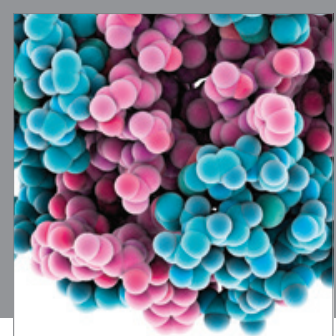

Journal of
Diabetes Research

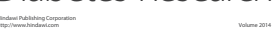

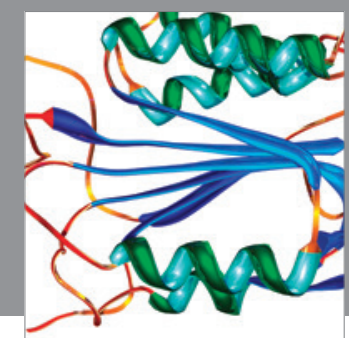

Disease Markers
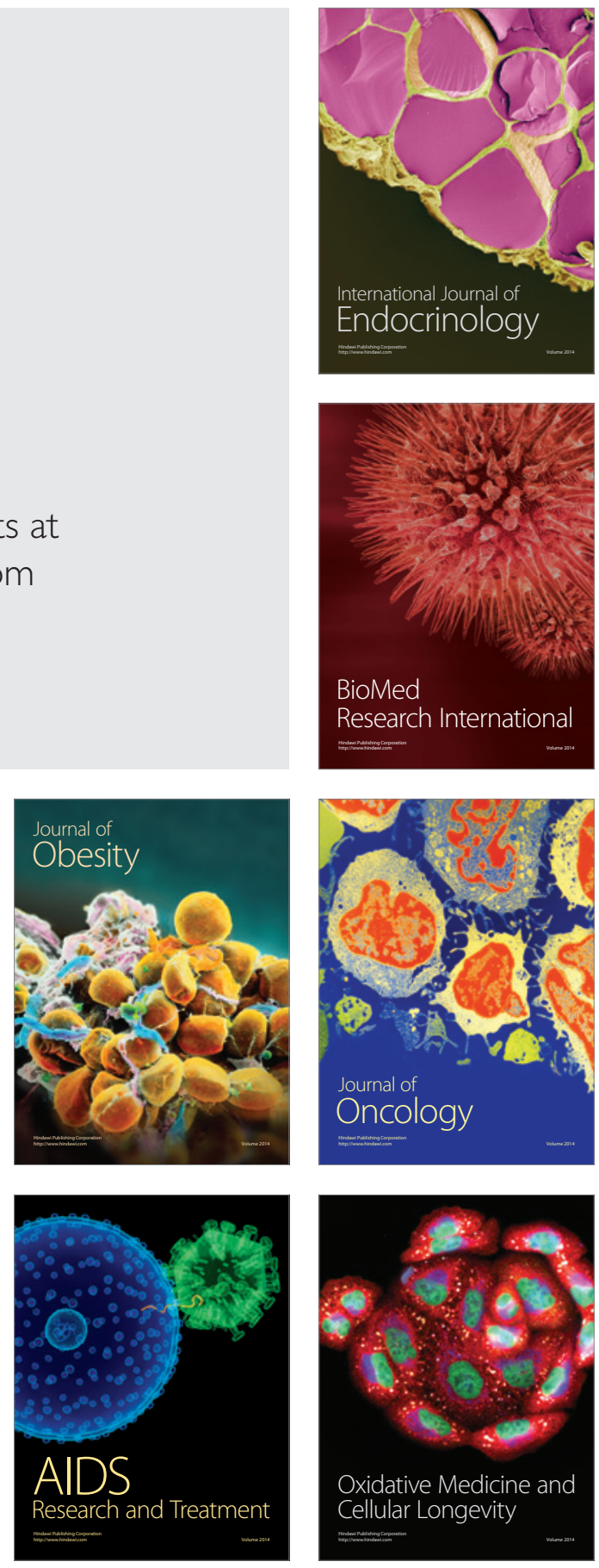